\title{
$\mathrm{PAC}_{1}$ 受容体および PACAP 遺伝子ノックアウトマウスの創出と その薬理学的解析
}

\author{
橋本 均 ${ }^{1)}$, 新谷 紀人 ${ }^{1)}$, 松田 敏夫 ${ }^{2)}$, 馬場 明道 ${ }^{1)}$ \\ ${ }^{1}$ 大阪大学 大学院 薬学研究科 神経薬理学分野, ${ }^{2}$ 同 複合薬物動態学分野
}

要 約 : ニューロペプチド、PACAP (pituitary adenylate cyclase-activating polypeptide)の神経系 における生理作用の解明を目的として、ES 細胞におけるジーンターゲティング法により PACAP 受容 体サブタイプの一つである $\mathrm{PAC}_{1}$ 受容体の遺伝子エクソン 2 ノックアウトマウス、および PACAP リ ガンド遺伝子ノックアウトマウスをそれぞれ作製し、各変異マウスについて PACAP シグナル系の機 能変化と個体の行動異常を薬理学的に解析した。まず 129 系マウスゲノム DNA ライブラリーより $\mathrm{PAC}_{1}$ 受容体および PACAP の遺伝子を単離し、構造を決定した。それらをもとに、ターゲティング ベクターを作製し、PAC 1 受容体は D3 株、PACAP は E 14 株の ES 細胞に導入して相同組換え体を得 て、同へテロおよびホモノックアウトマウス産仔を得た。 $\mathrm{PAC}_{1}$ 受容体ノックアウトマウスにおいて は、ターゲティングしたエクソンより下流から $\mathrm{N}$ 末に欠損のある産物が産生されていたものの、その 発現量は野生型よりも大幅に低下していた。一方、PACAPノックアウトマウスを行動薬理学に解析し た結果、その自発運動の充進が観察され、とくに情動関連行動に野生型と比較して明らかな変化が認 められた。

キーワード : PACAP、PAC 1 受容体、ジーンターゲティング、マウス、行動薬理学的解析

序 論 : PACAP はVIP (vasoactive intestinal polypeptide)、セクレチン、グルカゴンファミリー の一員であり、38 アミノ酸からなる PACAP38 とその $\mathrm{N}$ 末端の 27 アミノ酸からなる PACAP27 の二 つのフォームが天然に存在し、神経伝達物質、神経調節因子、神経ホルモンとしての働きがあること が知られている 1)。PACAP の生理作用の主なものは推定されているものも含めると以下の通りで ある 1)-8)。

1) 神経細胞分化一神経前駆細胞の交感アドレナリン作動性神経への分化因子作用があり、NGF と相 乗的に働く。2) 高次脳機能一海馬神経可塑性（長期増強）の発現を起こす。またショウジョウバエの 記憶障害変異遺伝子 amnesiac が、哺乳類 PACAP のホモログ遺伝子である。3) 発生期脳の器官形成 一七ト先天性脳奇形、全前脳症 3 型と 4 型遺伝子地図が PACAP 3 型受容体 (VPAC 2 受容体) および PACAP と一致する。4) 脳傷害保護作用一脳虚血再還流傷害モデルラットにおける海馬神経生存維持 作用を示す。5) 膵臓インスリン分泌の促進と $\beta$ 細胞保護作用一グルコース依存的インスリン分泌を促 進する（ラ氏島 $\beta$ 細胞間の協調的分泌に寄与する可能性）。また $\beta$ 細胞の障害に対する保護作用が示 唆されている。6) その他一副腎カテコラミン分泌、精子形成への関与、胃粘膜クロマフィン細胞增殖 作用、痛覚調節、免疫系の調節など。

これら各生理作用の発現において、PACAP シグナル系の特徴は次の通りである 1), 9)-13)。 
7) 受容体一PACAP の生理作用は、3 種のサブタイプからなる 7 回細胞膜貫通 $-\mathrm{G}$ 蛋白共役型受容体、 $\mathrm{PAC}_{1}$ 受容体、 $\mathrm{VPAC}_{1}$ 受容体および $\mathrm{VPAC}_{2}$ 受容体を介して細胞内に伝えられる。 $\mathrm{PAC}_{1}$ 受容体以外 の 2 つは、VIPにも PACAP と同程度の高親和性を持っている 9), 10)。

8）作用発現機構一少なくとも一部は、リガンドと受容体の共発現によるオートクリンーポジティブフ イードバック機構によることが推察される 3), 5), 6), 13)。

9) $\mathrm{PAC}_{1}$ 受容体の細胞内シグナル系とそれらの活性化に必要な PACAP 濃度

MAP キナーゼ (ERK) の活性化 約 $10^{-12} \mathrm{M}$

cAMP 産生促進約 $10^{-9} \mathrm{M}$

PI 代謝回転促進約 $10^{-8} \mathrm{M}$

$\mathrm{PAC}_{1}$ 受容体のリガンド結合の $\mathrm{Kd}$ 值は約 $10^{-9} \mathrm{M}$ であり、MAP キナーゼ系の活性化がその約 1,000 分の 1 の濃度で起きる機構は現在のところ不明である。PACAP の多様な働きにおいて、PAC 1 受容体 を介した MAP キナーゼの活性化は重要であると考えられることから、PACAP が in vivoにおいても 非常に低い濃度から神経機能などを調節しているものと推定される 13)。

PACAP の中枢神経系における in vivo 研究はリガンドの投与を行った報告などがあるが、特異性の 高いアンタゴニストがなかったためアゴニストによる実験が主であり、in vivo での㗢きの詳細は明ら かではなかった。我々は、PACAP シグナルの神経系における in vivo での働きを明らかにするために、 $\mathrm{PACAP}$ 選択的受容体である $\mathrm{PAC}_{1}$ 受容体と PACAP リガンドのノックアウトマウスを作製すること にした。そしてこれら各マウスについて、PACAP シグナル系の変化、行動関連の表現型の解析を進め ている。本シンポジウムではその結果について報告する。

結果および結論 : 129 系マウスゲノム DNA ライブラリーより $\mathrm{PAC}_{1}$ 受容体および $\mathrm{PACAP}$ の遺伝子を単離し、構造を決定した $\left.{ }^{14)}, 15\right)$ 。また我々は $\mathrm{VPAC}_{1}$ 受容体についても解析しており 4$) 、$ これら 3 つの遺伝子の特徵を表 1 にまとめる。

Table 1 Structural features of genes encoding mouse PACAP, $\mathrm{PAC}_{1}$ receptor, and $\mathrm{VPAC}_{1}$ receptor.

\begin{tabular}{|l|c|c|c|}
\hline & PACAP & PAC $_{1}$ receptor & VPAC $_{1}$ receptor \\
\hline Gene length & $6.6 \mathrm{~kb}$ & $>50 \mathrm{~kb}$ & $>16 \mathrm{~kb}$ \\
\hline Number of exons & 6 & 18 & 13 \\
\hline Number of alternative exons & 2 & 2 & 0 \\
\hline Chromosomal localization & - & - & $\begin{array}{c}\text { Chromosome 9 } \\
\text { (Distal region) }\end{array}$ \\
\hline
\end{tabular}

次いで、マウス $\mathrm{PAC}_{1}$ 受容体および PACAP ゲノム DNA を用いてターゲティングベクターを作製 し、ES 細胞の相同組換え体を単離して、同へテロおよびホモノックアウトマウス産仔を得た。ノック アウトマウスの作製の概要を表 2 によとめる。 
Table 2 Generation of $\mathrm{PAC}_{1}$ receptor and PACAP knockout mice.

\begin{tabular}{|l|c|c|}
\hline & PAC $_{1}$ receptor & PACAP \\
\hline Type of targeting vector & Replacement type & Replacement type \\
Targeted region & Exon 2 & Exon 5 \\
Positive selection & PGK-neo & PGK-neo \\
Negative selection & HSV-tk & DT-A \\
5' Homologous region & $10.4 \mathrm{~kb}$ & $5.3 \mathrm{~kb}$ \\
3' Homologous region & $1.5 \mathrm{~kb}$ & $2.1 \mathrm{~kb}$ \\
\hline ES cell & D3 & E14 \\
\hline Screening method & Nested PCR, Southern blotting & Southern blotting \\
\hline Frequency of homologous recom- & $4 / 552(0.72 \%)$ & $4 / 244(1.6 \%)$ \\
bination & & Blastocyst injection \\
\hline Chimera generation & 1 line & 2 lines \\
\hline Germline chimera & $129 /$ SvJ $\times$ C57BL/6 & $129 /$ Ola $\times$ C57BL/6 \\
\hline Genetic background &
\end{tabular}

$\mathrm{PAC}_{1}$ 受容体ノックアウトマウス ${ }^{16)}$ : 翻訳開始 ATG コドンおよびシグナルペプチドの一部を コードするエクソン 2 を置換する方法によりターゲティングを行った結果、エクソンより下流から N 末に欠損のある産物が産生されていたものの、その発現量は野生型よりも大幅に低下していた。シグ ナルペプチド欠損型受容体について発現系を用いて調べたところ、野生型受容体に顕著に見られる糖 鎖付加がほとんど起こらず、細胞内の核周辺に多く局在することが明らかになった。しかし、変異型 受容体は細胞膜上にもわずかながら移行し、細胞内情報伝達系への連関も認められた。現在、本マウ スの組織、個体レベルの表現型について解析中である。

PACAP ノックアウトマウス : ホモマウスのPACAP の発現は完全に消失していた。またワイル ド、へテロ、ホモ遺伝型の割合は、ホモが Mendelian frequency よりも低かった。行動薬理学に解析 した結果、ホモマウスにおいて自発運動の充進が観察され、とくに情動関連行動に野生型と比較して 明らかな差異が認められた。現在、行動薬理学的検討に加えて、その異常の原因を明らかにするため に神経薬理学的な解析を進めている。 


\section{文 献：}

1) Arimura A: Perspectives on pituitary adenylate cyclase activating polypeptide (PACAP) in the neuroendocrine, endocrine, and nervous systems. Jpn J Physiol 48, 301-331 (1998)

2) 橋本 均, 馬場 明道: Pituitary adenylate cyclase-activating polypeptide (PACAP)受容体の構造およ び機能. ビ夕ミン 71, 285-296 (1997)

3) Hashimoto H, Hagihara N, Koga K, Yamamoto K, Shintani N, Tomimoto S, Mori W, Matsuda T and Baba A: Synergistic induction of pituitary adenylate cyclase-activating polypeptide (PACAP) gene expression by nerve growth factor and PACAP in PC12 cells. J Neurochem 74, 501-507 (2000)

4) Hashimoto H, Nishino A, Shintani N, Hagihara N, Copeland N-G, Jenkins N-A, Yamamoto K, Matsuda T, Ishihara T, Nagata S et al: Genomic organization and chromosomal location of the mouse vasoactive intestinal polypeptide $1\left(\mathrm{VPAC}_{1}\right)$ receptor. Genomics 58, 90-93 (1999)

5) Nogi H, Hashimoto H, Fujita T, Hagihara N, Matsuda T and Baba A: Pituitary adenylate cyclaseactivating polypeptide (PACAP) receptor mRNA in the rat adrenal gland: localization by in situ hybridization and identification of splice variants. Jpn J Pharmacol 75, 203-207 (1997)

6) Nogi H, Hashimoto H, Hagihara N, Shimada S, Yamamoto K. Matsuda T, Tohyama M and Baba A: Distribution of mRNAs for pituitary adenylate cyclase-activating polypeptide (PACAP), PACAP receptor, vasoactive intestinal polypeptide (VIP), and VIP receptors in the rat superior cervical ganglion. Neurosci Lett 227, 37-40 (1997)

7) Hashimoto H, Nogi H. Mori K, Ohishi H, Shigemoto R, Yamamoto K, Matsuda T, Mizuno N, Nagata $S$ and Baba A: Distribution of the mRNA for a pituitary adenylate cyclase-activating polypeptide receptor in the rat brain: an in situ hybridization study. J Comp Neurol 371, 567-577 (1996)

8) Kondo K, Hashimoto H, Sakata K, Saga H, Kitanaka J and Baba A: Stimulation of cyclic AMP formation by pituitary adenylate cyclase-activating polypeptide is attenuated by glutamate in rat brain slices. Jpn J Pharmacol 67, 399-401 (1995)

9) Hashimoto H, Ishihara T, Shigemoto R, Mori K and Nagata S: Molecular cloning and tissue distribution of a receptor for pituitary adenylate cyclase-activating polypeptide. Neuron 11, 333342 (1993)

10) Hashimoto H, Yamamoto K, Hagihara N, Ogawa N, Nishino A, Aino H, Nogi H, Imanishi K, Matsuda T and Baba A: cDNA cloning of a mouse pituitary adenylate cyclase-activating polypeptide receptor. Biochim Biophys Acta 1281, 129-133 (1996)

11) Hashimoto $H$, Aino $H$, Ogawa $N$, Nagata $S$ and Baba A: Identification and characterization of parathyroid hormone/parathyroid hormone-related peptide receptor in cultured astrocytes. Biochem Biophys Res Commun 200, $1042-1048$ (1994)

12) Hashimoto H, Ogawa N, Hagihara N, Yamamoto K, Imanishi K, Nogi H, Nishino A, Fujita T, Matsuda T, Nagata S et al: Vasoactive intestinal polypeptide and pituitary adenylate cyclaseactivating polypeptide receptor chimeras reveal domains that determine specificity of vasoactive intestinal polypeptide binding and activation. Mol Pharmacol 52, 128-135 (1997)

13) 橋本 均: ニューロペプチドPACAPの生理的役割とそのしくみ. 生化学 72, 191-193 (2000)

14) Aino H, Hashimoto H, Ogawa N, Nishino A, Yamamoto K, Nogi H, Nagata S and Baba A: 
Structure of the gene encoding the mouse pituitary adenylate cyclase-activating polypeptide receptor. Gene 164, 301-304 (1995)

15) Yamamoto K, Hashimoto H, Hagihara N, Nishino A, Fujita T, Matsuda T and Baba A: Cloning and characterization of the mouse pituitary adenylate cyclase-activating polypeptide (PACAP) gene. Gene 211,63-69 (1998)

16) Hashimoto H, Shintani N, Nishino A, Okabe M, Ikawa M, Matsuyama S, Itoh K, Yamamoto K, Tomimoto $\mathrm{S}$, Fujita $\mathrm{T}$ et al: Mice with markedly reduced PACAP $\left(\mathrm{PAC}_{1}\right)$ receptor expression by targeted deletion of the signal peptide. J Neurochem (2000) in press

Abstract- Generation and pharmacological analysis of $\mathrm{PAC}_{1}$ receptor and PACAP knockout mice. Hitoshi Hashimoto. Norihito Shintani, *Toshio Matsuda, and Akemichi Baba Laboratories of Molecular Neuropharmacology and *Medicinal Pharmacology, Graduate School of Pharmaceutical Sciences, Osaka University, Suita, Osaka 565-0871, Japan

Folia Pharmacol. Jpn. (Nippon Yakurigaku Zasshi) 116, Suppl 1, 116P 120P (2000) In an attempt to study the pituitary adenylate cyclase-activating polypeptide (PACAP)-mediated signaling functions in vivo, we have used gene targeting in embryonic stem cells to disrupt exon 2 of the PACAP type I receptor $\left(\mathrm{PAC}_{1}\right.$ receptor) gene, which contains the ATG translation start site and the signal peptide. Unexpectedly, active transcription of $\mathrm{PAC}_{1}$ receptor $\mathrm{mRNA}$ was detected in the mutant mice, although ligand binding in the brain was greatly reduced. $\mathrm{PAC}_{1}$ receptor exon $2^{-/-}$mice were apparently normal and fertile. The expression study of the mutant receptor lacking the signal peptide showed that the signal peptide is required for efficient cell surface expression and $\mathrm{N}$-linked glycosylation of the $\mathrm{PAC}_{1}$ receptor. We also generated mice lacking PACAP ligand by targeted deletion of the PACAP gene exon 5. PACAP-null mice developed to adulthood at a frequency lower than expected by mendelian genetics, and were hyperactive and showed reduced anxiety. Neurochemical characterization of these mice is currently under investigation.

Keywords: PACAP, $\mathrm{PAC}_{1}$ receptor, gene targeting, mouse, ethopharmacological analysis. 